\title{
Nadītum-Women in the Field Lease Contracts from Sippar
}

\author{
Ichiro NAKATA
}

The Society for Near Eastern Studies in Japan (NIPPON ORIENTO GAKKAI) 


\title{
Nadītum-Women in the Field Lease Contracts from Sippar
}

\author{
Ichiro NAKATA*
}

\begin{abstract}
This article surveys the economic activities of the naditum-women cloistered in Sippar, as reflected in the Old Babylonian field lease contracts published by L. Dekiere in MHET II/1-6. The survey addresses the size of the leased fields, the subsistence level of a farmer in that period, rental rates, the timing of concluding a field leasing contract, locations of fields, and the amount of the land held by some of the prominent naditum-women. Some naditumwomen accumulated as much as $44 \mathrm{iku}$ (about 15.8 hectatres) or even $70 \mathrm{iku}$ (25.2 hectares) of land to lease during their residency in the cloister and can be characterized as women entrepreneurs.
\end{abstract}

Keywords: agriculture, alternate fallow system, field leasing, nadītum-woman, Sippar

\section{Introduction}

A total of 932 Old Babylonian real estate texts from Sippar housed in the British Museum were published in transliteration by L. Dekiere from 1994 to 1997. ${ }^{1}$ The texts in MHET II/1-4 are arranged in chronological order, ${ }^{2}$ while those texts whose date is lost or not recorded are published in MHET II/5. According to Dekiere (1996, 1), 179 of the 279 texts in MHET II/5 could be assigned a relative date, and additional twenty-eight texts with a broken year name or unknown year name could be dated after cleaning and collation. The texts published in MHET II/6 are from the "Series" 1902-10-11 in the British Museum and are also arranged chronologically from Sabium (1844-1831 BC) to Ammi-ṣaduqa (1646-1626 BC).

A glance at the catalogues attached to Parts 1-6 of MHET II shows that the field lease contracts are generally the most numerous type of text, followed by the field sales contracts. The only exception is the case of real estate texts in MHET II/1 dated to the pre-Hammurabi period. Here, only four field lease contracts are found, as opposed to thirty-five field sale contracts according to my count (see Table 1 below). The ratio of the numbers of the two types of texts in MHET II/1 (4:35) is more or less in agreement with their 6:40 ratio in the texts from preHammurabi Sippar that were available to R. Harris at the time of the publication of her Ancient Sippar (Harris 1975, 217-220, 229-233).

\footnotetext{
* Professor Emeritus, Chuo University and Director, the Ancient Orient Museum, Tokyo

Abbreviations used in the present study follow the Cuneiform Digital Library Initiative (CDLI; abbreviations are listed at http://cdli.ox.ac.uk/wiki/abbreviations_for_assyriology).

1 L. Dekiere, Old Babylonian Real Estate Documents from Sippar in the British Museum, Mesopotamian History and Environment, Series III, Texts (hereafter MHET), II/1 and II/2, Ghent, 1994, MHET II/3 and II/4, 1995, MHET II/5, 1996 and MHET II/6, 1997. For a review of MHET II, see Woestenburg 1997-98, 349-360. See also Kalla 1999, 201-226.

2 The texts of MHET II/1 are dated to the pre-Hammurabi period, while those of MHET II/2 and those of MHET II/3 are dated to Hammurabi period (1792-1750 BC) and Samsu-iluna period (1749-1712 BC) respectively. MHET II/4 contains texts dated to the post-Samsu-iluna period.
} 
In the field lease contracts and the field sales contracts published in MHET II/1-6, the majority of the lessors in the former except in MHET II/4 and II/6 and the majority of the purchasers in the latter except in MHET II/5 and 6 are women, as the figures in parentheses in Table 1 show. Those women are quite likely to have been nadītum-women of Šamaš, who lived in the "cloister (gagum)" in Sippar even when they are not so specified. The women who leased out their fields acquired them partly through bequest ${ }^{3}$ from their father or brother(s), when their father had deceased, and partly through purchase. ${ }^{4}$

Table 1: Numbers of Field Lease and Field Sale Contracts

\begin{tabular}{|c|c|c|}
\hline Publication & Field Lease Contracts & Field Sale Contracts \\
\hline MHET II/1 & $4(4)$ & $35(19)$ \\
\hline MHET II/2 & $92(90)$ & $15(13)$ \\
\hline MHET II/3 & $46(41)$ & $9(7)$ \\
\hline MHET II/4 & $63(23)$ & $9(8)$ \\
\hline MHET II/5 & $137(116)$ & $26(8)$ \\
\hline MHET II/6 & $22(4)$ & $4(2)$ \\
\hline
\end{tabular}

Note: The figure in parentheses shows the number of the texts with a woman lessor or purchaser of a field (a.šà).

In the 1960s and the 1970s, R. Harris published detailed studies on the naditum-women dedicated to God Šamaš of Sippar based on the pertinent documents available to her. J. Renger (1967, 149-168) also dealt with the nadītum-women of Šamaš in his exhaustive study of the priesthood of the Old Babylonian period. Since then, however, more than 350 new real estate texts from Sippar involving (naditum-)women as lessors or purchasers of field or beneficiaries of bequest have become available thanks to L. Dekiere. Thus, new studies based on these texts are warranted.

In this paper, I would like to examine the field lease contracts with a (naditum-)woman as lessor published in MHET II/1-6.

\section{The Acreage of the Field for Leasing}

There are two types of field lease contracts: one with an indication of the specific acreage of the field for leasing and the other without (cf. a.šà mala mașî́ ${ }^{6}$ or a.šà mala qāssunu ikaššadu').

When the acreage is indicated, a field for leasing is $2 \mathrm{iku}$ (approximately $0.72 \mathrm{ha}$ ) or larger

\footnotetext{
3 For example, Bēltani (nadìtum-woman), received a field of 12 iku together with a house in the cloister (gagûm) as bequest from her father Ipquša (MHET II/2, 171), while Mannaši (nadītum-woman) received a field of 5 iku among others as bequest from her father Sîn-šadûni (MHET II/2, 255).

4 For the field purchasing by nadītum-women in Sippar as reflected in MHET II/1-6, see Nakata (forthcoming).

5 This paper is a combined and much revised version of my two earlier papers read at the second (June 25, 2013, Tokyo) and third (September 3, 2013, Carqueiranne) REFEMA workshops (on "Le rôle économique des femmes en mésopotamie ancienne"). A preliminary Japanese version of this paper was published in the Report: December 31, 2011-December 30, 2014. A Bilateral Joint Research Project with France on "Women's Role in the Economy of the Ancient Near East," 102-120. (http://f.hypotheses.org/wp-content/blogs.dir/1047/files/2015/01/Texts.pdf).

6 The "field as much as is found" (MHET II/1, 120, 125; II/2, 239, 270, 287; II/3, 346, 363, 404, 461; II/4, 490, 495, $\underline{512}, \underline{527}, \underline{541}, 542,562, \underline{563} ; \mathrm{II} / 5, \underline{566}, \underline{587}, \underline{653}, 687, \underline{690}, 762,774,794,806 ; \mathrm{II} / 6,909$. The underlined textual number indicates that the field lease contract under question has a man [or men] as lessor[s]). Cf. Mauer 1980, 19-20.

7 The "field as much as their hand can reach"(MHET II/ 4, 483; II/6, 899). Cf. Mauer 1980, 19-20.
} 
with a few exceptions. ${ }^{8}$ One popular acreage of fields for leasing on the lower end of the scale is $3 \mathrm{iku}$ (for example, nineteen field lease contracts $^{9}$ with a (naditum-)woman as lessor in MHET $\mathrm{II} / 2$ and II/3 alone). $6 \mathrm{iku}$ is another popular size for leased fields (sixteen field lease contracts ${ }^{10}$ again in MHET II/2 and II/3 alone). However, the $18 \mathrm{iku}$ (= 1 bùr) or more is not rare for acreage of leased fields on the high end of the scale (five field leasing contracts for $18 \mathrm{iku}$ and two leasing contracts for $19 \mathrm{iku}) .{ }^{11}$ It may be of interest that the acreage of fields leased out by naditumwomen is often multiples of $3 \mathrm{iku}$.

\section{The Minimum Acreage Needed for a Naditum-Woman to Subsist}

In order to evaluate this data properly, it is necessary to know the minimum field acreage required for the subsistence of an average individual.

J. Oates $(1980,307)$ states that 6 hectares (about $16.7 \mathrm{iku}$ ) of land constitute the minimum necessary to support an average family of six persons under conditions of plough agriculture in the alternate fallow system. This means that the minimum acreage for one person to live on was 1 hectare (about $2.8 \mathrm{iku}$ ). ${ }^{12}$ This is supported, according to J. Oates $(1980,307)$, by the minimum allotment of a field of 1 bùr (18 iku or approximately 6.48 hectares) of field to an älik ilkim, a holder of ilkum-obligations and his family at the time of Hammurabi.

E. Stone and D. L. Owen compare the higher level of support (720 sìla or $540 \mathrm{KWE}$ [kilogram wheat equivalent]) per year for a male adopter by a male adoptee in OB adoption contracts from Nippur with the figure of $536 \mathrm{~kg}$ wheat equivalent (KWE) per year that C. Clark and M. Haswell (1970, 81 [apud Stone and Owen 1991, 9]) suggested as the average subsistence level in Iraq during 1950s. The equivalent in barley of $536 \mathrm{KWE}$ would be about 713 liters. ${ }^{13}$

M. Stol $(1998,64)$ made a survey of the annual allowances for people "as long as they live" and came up with the figure of 2 liters of barley per day or 720 liters per year per person. Since he posits that the expected yield of barley from a field of $1 \mathrm{iku}$ is 400 liters, ${ }^{14}$ the subsistence level in terms of acreage of the field for a person under conditions of plough agriculture in the alternate fallow system would be about $3.6 \mathrm{iku}(720$ litres $\div 400$ liters [the expected yield per iku per year] $\times 2^{15}$ ) or approximately 1.3 hectares.

\footnotetext{
MHET II/3, 366 is one such exception. Here, Nanna-ibila-mansum apparently rented a field of 1 iku for cultivation from a woman named Amat-Šamaš for the rent of 1 gur (300 liters) of barley.

9 MHET II/2, 144, 157, 187, 194, 198, 213, 254, 259, 269, 279, 289, 296, 304, 309; II/3, 351, 360, 375, $376,391$.

${ }^{10}$ MHET II/2, 156, 166, 174, 178, 179, 185, 192, 196, 201, 207, 260, 274, 293, 310; II/3, 382, 419.

${ }^{11}$ MHET II/2, 160, 306, 323; II/3, 377, 441 (all $18 \mathrm{iku}$ ), and MHET II/2, 273; II/3, 368 (19 iku). According to MHET II/3, 443, $24 \mathrm{iku}$ of field is leased out by Ruttum, daughter of İși-Qatar. However, something must be wrong with this text, because the tenant in this contract is expected to give 37 gur of barley as rent $(115.6 \%)$ to Ruttum, daughter of İși-Qatar, the landlady.

${ }^{12}$ I am giving here only a very rough estimate. A family of six persons might have included a baby or babies.

${ }^{13}$ Calculated by multiplying $536 \mathrm{KWE}$ by a conversion rate of 1.33 ( $1 \mathrm{KWE}=1.33$ sila which is approximately 1.33 liters). This conversion rate is based on the data given in Table 3 in Stone and Owen 1991, 8, as corrected by M. Stol (1998, 67 n. 33).

14 Stol 1991, 69 n. 39. However, K. Maekawa $(2011,72)$ says that an expected yield of barley from a field of 1 bùr is 30 gur, in other words 500 liters per $1 \mathrm{iku}$ of a field, based on his study of Ur III agricultural texts. I will use M. Stol's figure for calculation, thinking that the yield per iku in the Old Babylonian period may have dropped slightly due to increased salinization.

${ }^{15}$ Please note that in the alternate fallow system a field produces a yield only every other year.
} 
Now, if we suppose that a naditum-woman lives by herself ${ }^{16}$ and solely on the rent(s) coming from the fields she has, she must have at least a total of $5.4 \mathrm{iku}$ (approximately 1.9 hectares) of fields under cultivation in any given year. A total of $5.4 \mathrm{iku}$ of fields would theoretically produce a yield of 2,160 liters of barley at the harvest. Even under the less favorable " $1 / 3$ contract" she would then receive a rent of 720 liters of barley that would be sufficient for her subsistence. In the alternate fallow system, this would mean that she must have, at least, a total of $10.8 \mathrm{iku}$ (5.4 $\mathrm{iku} \times 2$ ) of fields in two or more irrigation districts.

It is interesting to note in this connection that, according to a late Old Babylonian text from Sippar-Amnānum, ${ }^{17}$ nine of the ten bā' irum-soldiers are allotted a total of $12 \mathrm{iku}$ of fields each as subsistence allotments (șibtum-fields) in two or four different irrigation districts. ${ }^{18}$ The bā'irumsoldiers appearing in this text could probably support themselves and their family of three or four persons with the yield from these sibtum-fields, even if they had to give a part of the yield to the landlord (the state in this case).

\section{The Rent of the Field}

The rent was paid in kind at the time of harvest and is fixed to one third of the yield in 35 (26.7\%) of the 131 field lease contracts with a woman as lessor published in MHET II/2 and 3 according to my count. ${ }^{19}$ However, we find rents much more favorable to the landladies such as $50 \%$ of the yield in ten field lease contracts $(7.6 \%)^{20}$ and $75 \%$ of the yield in twenty-two field lease contracts $(16.8 \%)^{21}$ published in MHET II/2 and 3. In the remaining field lease contracts, however, the rent varies. ${ }^{22}$ We find such a low rate as 15\% (MHET II/2, 198), but we also find such high rates as $87.5 \%$ (MHET II/3, 351) and 87.9\% (MHET II/2, 280). ${ }^{23}$

Furthermore, tenants are required to give, in addition, 1 or 2 bán of flour ( 1 bán = about 10 liters) and a piece of meat to the landlady of the field (ipaqqissi) on the occasions of three to six festivals of Šamaš per year. The rent is usually required to be measured (i.ág.e) at the gate of the

\footnotetext{
${ }^{16}$ Not a few naditum-women seem to have lived with one or more male and/or female slaves. Thirteen (approximately $31 \%$ ) of the forty-two bequest documents published in MHET II/1-6, in which a woman is beneficiary of the bequest, included at least one male or female slave among the items of bequest in addition to the land (MHET II/1, 18 [one female slave], 19 [one male and one female slaves], 99 [one female slave], 117 [one male and one female slaves], II/2, 243 [one female slave], 255 [one male and one female slaves], 333 [at least two female slaves], II/3, 367 [one female slave], II/5, 570 [two male and two female slaves], 816 [one female slave], 853 [two female slaves], II/6, 862 [four male and three [or four] female slaves], 881 [two male slaves]). Harris stated that every nadìtum-woman had at least one slave (Harris 1964, 13f.).

${ }^{17}$ MHET II/6, 894.

${ }_{18}^{18}$ MHET II/6, 894. This text has been studied by De Graef 2002, 141-178.

${ }^{19}$ MHET II/2, 150, 151, 155, 175, 177, 179, 185, 195, 207, 208, 219, 222, 228, 237, 262, 270, 272, 283, 285, 287, 295, 296, 304, 309; II/3, 346, 348, 350, 360, 361, 363, 364, 365, 385, 395, 403.

${ }^{20}$ MHET II/2, 174, 194, 213, 247, 279, 289; II/3, 376, 377, 419, 441. Let us recall that $\S 46$ of the Code of Hammurabi mentions the $1 / 3$ contract and the $1 / 2$ contract as the rental rates for tenant farmers.

${ }^{21}$ MHET II/2, 144, 157, 187, 196, 201, 229, 232, 235, 236, 244, 259, 260, 269, 274, 288, 302, 307; II/3, 352, 362, 366, 380,428 .

${ }^{22}$ According to Harris $(1975,225)$, "The ratio paid to the owner was usually 6 GUR of barley per 18 GÁN (or 1 BUR) which is $1 / 3$ GUR per GÁN, though the ratio is often slightly higher- 8 GUR per 18 GÁN (or 1 BUR), or even about 1 GUR per GÁN." She adds further, "It appears that the owner was favored at the beginning of the reign of Hammurapi, and perhaps slightly before and after. After this the owner's share became more standardized: one-third of the yield."

${ }^{23}$ We even find a field lease contract (MHET II/2, 305) according to which Erišti-Aya, the owner of the field, requires her tenant to give 4 gur (= about 1,200 liters) of barley for a field of $50 \mathrm{sar}(1 / 2 \mathrm{iku})$. This means an impossible rate of $600 \%$.
} 
cloister, but in one instance (MHET II/2, 192) at the temple of Šamaš. ${ }^{24}$

\section{Timing for Concluding a Field Lease Contract}

Normally a field lease contract is for one year. However, MHET II/2, 166 for example, is for two years, while three field lease contracts (MHET II/2, 142, 148 and 156) are for three years. ${ }^{25}$

Perusing forty leasing contracts in MHET II/2 and II/3 dated to the reigns of Hammurabi and Samsu-iluna respectively that contain not only a year name but also a month name, I have found all the month names except Month VII (September/October) and Month X (December/ January). However, twenty-five $(62.5 \%)^{26}$ of the forty leasing contracts were concluded during the period from Month I (March/April) to Month III (May/June), namely between the beginning of the annual inundation of the Euphrates River and its inundation peak. The rest of the leasing contracts were concluded in Month IV (MHET II/2, 289 and 306), Month V (MHET II/2, 174), Month VI (MHET II/2, 291 and II/5, 610), Month VIII (MHET II/2, 237, 253 and MHET II/3, 382), Month IX (MHET II/2, 235), Month XI (MHET II/2, 208, 231 and MHET II/3, 368) or Month XII (MHET II/2, 185, 223 and 249). The leasing contracts dated to Months IV-VI may have been concluded rather late for the season, while those of Months VIII-XII may have been concluded early for the coming agricultural season.

\section{Lessees of the Field Lease Contracts}

Here I would like to refer to a statement by R. Harris $(1975,223)$, because my prosopographical data and analysis is not yet sufficient:

The occupation of the lessee is not specified before the time of Ammi-ditana, but the occupations mentioned from this period onward indicate that those renting fields are often affluent individuals, who did so as investments. Fields are rented by such well-to-do people as a sanga of the Gula temple, scribes, a diviner, a judge, a general, a rabiānu official, the abi șäbi officials, barbers, and the overseer of the barbers, a shepherd and a gardener. Among the perhaps less affluent lessees are a house-builder, fisherman, and Suteans.

\section{Some Prominent (Nadītum-)Women in the Field Lease Contracts}

There are twenty-two women who appear as lessor in three or more field lease contracts published in MHET II/1-6. Six of them are not clearly identified as a nadītum (lukur), but it is quite likely that they too were naditum-women. Following are the names of these twenty-two women together with the date of each field lease contract in abbreviation, ${ }^{27}$ the acreage and the

\footnotetext{
${ }^{24}$ This requirement is probably related to the compulsory use of measures authorized by the Šamaš temple. However, is it possible to conjecture that a percentage of the rents of naditum-women's fields constituted a part of the revenue of the Šamaš temple?

${ }^{25}$ I cannot reconcile these two- or three-year contracts with the alternate fallow system that I believe was in practice in Babylonia. See my Excursus at the end of this article.

${ }^{26}$ Month I: MHET II/2, 144, 201, 263, 271, 271, 273, 302, 312; MHET II/3, 397, 404. Month II: MHET II/2, 195, 247, 274, 288, 307, 313; MHET II/3, 350, 351, MHET II/6, 857. Month III: MHET II/2, 173, 196, 204, 212, 222; MHET $\mathrm{II} / 3,443$.

${ }^{27}$ H27 stands for Hammurabi's $27^{\text {th }}$ regnal year. Likewise, Sm for Sîn-muballit and Si for Samsu-iluna. A dash “- indicates missing data.
} 
location of the field leased, and their textual references in parentheses.

Amat-kallātim (nadītum), daughter of Šamaš-ilum

H18: $6 \mathrm{iku} /$ ZA HA x num (MHET II/2, 192)

H28: $12 \mathrm{iku} /$ ša-Nahanim (MHET II/2, 228)

H32: $12 \mathrm{iku} /$ ša-Nahanim (MHET II/2, 247)

- : $\quad 3 \mathrm{iku} /$ - (MHET II/5, 730)

Amat-Šamaš (nadītum), daughter of Mašum

H27: 2 iku / Pahuṣum (MHET II/2, 229)

H29: $2 \mathrm{iku} /$ Pahușum (MHET II/2, 235)

H40: $2 \mathrm{iku} /$ - (MHET II/2, 288)

Amat-Šamaš (nadītum), daughter of Sîn-iddinam

H09: $9 \mathrm{iku} /$ Iplahi (MHET II/2, 150)

H09: $9 \mathrm{iku} /$ Iplahi (MHET II/2, 151)

—: $9 \mathrm{iku} /$ - (MHET II/5, 737)

Amat-Šamaš, daughter of Warad-Šamaš

Si02: $1 \mathrm{iku} /$ Lugal.sag.íla (MHET II/3, 366)

Si03: 3 iku / ša-Našuriš (MHET II/3, 376)

Si05: 3 iku / Pahușum (MHET II/3, 391)

Aya-tallik (nadītum), daughter of Ahulap-Šamaš

$\mathrm{H}$-: $\quad 3 \mathrm{iku} /$ a.gàr GAL (MHET II/5, 688)

H-: $\quad 3 \mathrm{iku} /$ a.gàr gu.la (MHET II/5, 694)

— : $9 \mathrm{iku} \mathrm{/} \mathrm{a.gàr} \mathrm{GAL} \mathrm{(MHET} \mathrm{II/5,} \mathrm{830)}$

Bēlessunu (nadìtum), daughter of Kazatum

H41: $3 \mathrm{iku} /$ Balala (MHET II/2, 296)

H42: $3 \mathrm{iku} /$ Balala (MHET II/2, 304)

H43: 3 iku / Tawirātum (MHET II/2, 309)

Si02: $3 \mathrm{iku} /$ Balala (MHET II/3, 360)

H- : $3 \mathrm{iku} /$ Balala (MHET II/5, 759)

H- : $\quad 5 \frac{1}{2} \mathrm{iku} /$ Nadiātum; $3 \mathrm{iku} /$ Balala (MHET II/5, 793)

$\mathrm{H}-$ : $\quad 4 \frac{1}{2} \mathrm{iku} /$ - (MHET II/5, 797)

Eli-erēssa (nadītum), daughter of Akiyatum

H26: 5 iku / Ṭābum (MHET II/2, 220)

H40: 5 iku 30 sar / Ṭābum (MHET II/2, 284)

— : $\quad 5 \mathrm{iku} /$ Țābum (MHET II/5, 801)

— : $5 \mathrm{iku} /$ Ṭābum (MHET II/5, 809)

— : 5 iku 20 sar / Ṭābum (MHET II/5, 812)

Eli-erēssa (nadītum), daughter of Sîn-abušu

Si01: mala maṣû / Ebirtum (MHET II/3, 346)

Si03: $4 \mathrm{iku} /$ birìt nārîm (MHET II/3, 381)

Si03: $6 \mathrm{iku} /$ Saškum (MHET II/3, 382) 
Si09: 4 iku / birīt nārîm (MHET II/3, 403)

— : $1 \mathrm{iku} /$ birìt nārim (MHET II/5, 655)

Erišti(nin-ti)-Aya, daughter of Nabī-ilišu

H15: $6 \mathrm{iku} / \mathrm{Huba}$ (MHET II/2, 178)

H17: $6 \mathrm{iku} /$ erasure (MHET II/2, 196)

H18: $6 \mathrm{iku} / \mathrm{Huba}$ (MHET II/2, 201)

H38: mala maș̂u / a.gàr GAL (MHET II/2, 270)

H38: mala mașû / — (MHET II/2, 272)

H40: $4 \mathrm{iku} / \mathrm{Huba}(\mathrm{MHET}$ II/2, 285)

H42: $\quad 50 \mathrm{sar} /$ - $(\text { MHET II/2, 305 })^{28}$

$\mathrm{H}$-: $\quad 5 \mathrm{iku} /$ a.gàr gu.la (MHET II/5, 756)

H-: $3 \mathrm{iku} /$ Huba (MHET II/5, 761)

— : $3 \mathrm{iku} /$ ša-Sîn (MHET II/5, 751)

— : $40 \mathrm{sar} /$ - (MHET II/5, 783)

—: mala mașû / — (MHET II/5, 806)

— : $6 \mathrm{iku} /$ Huba (MHET II/5, 820)

Erišti-Aya, daughter of Bununum

— : $5 \mathrm{iku} \mathrm{/} \mathrm{a.gàr} \mathrm{gu.la} \mathrm{(MHET} \mathrm{II/5,} \mathrm{722)}$

— : $5 \mathrm{iku} /$ - (MHET II/5, 728)

— : $1 \mathrm{iku}+$ / a.gàr GAL (MHET II/5, 767)

— : — - (MHET II/5, 782)

Huššutum (nadìtum), daughter of Sîn-puṭram

Sm06: 10 iku / Pahușum (MHET II/1, 113)

H11: $18 \mathrm{iku} /$ Pahușum (MHET II/2, 160)

H16: $3 \mathrm{iku} /$ ša-Našuriš (MHET II/2, 187)

H20: $18 \mathrm{iku} /$ Pahuṣum (MHET II/5, 610)

H32: $4 \mathrm{iku}+/$ ša-Ninkarrak (MHET II/2,249)

— : _ _ Pahusum (MHET II/5, 824)

Huzālatum (nadītum), daughter of Sumurah

H15: 6 iku / Saškum (MHET II/2, 179)

H17: 4 iku / Nagûm (MHET II/2, 193)

H22: $6 \mathrm{iku} /$ Saškum (MHET II/2, 207)

H30: 4 iku / birìt nārîm (MHET II/2, 237)

H35: $6 \mathrm{iku} /$ ša-Amkanum (MHET II/2, 260)

H35: 4 iku / Nagûm (MHET II/2, 261)

H40: 4 iku / Nagûm (MHET II/2, 283)

H40: $\quad$ mala mașû / Saškum (MHET II/2, 287)

H41: 4 iku / Hुașārum (MHET II/2, 295)

H-: $6 \mathrm{iku} /$ Saškum (MHET II/5, 749)

${ }^{28}$ This text may be excluded, because the field of 50 sar $(0.5 \mathrm{iku})$ is leased out for planting vegetable (ana šiknim ušeși) and not barley. 
Si15: $4 \mathrm{iku} /$ - (MHET II/3, 428)

- : mala mașû / Saškum (MHET II/5, 762)

— : $6 \mathrm{iku} /$ Saškum (MHET II/5, 779)

—: $6 \mathrm{iku} /$ a.gàr gu.la (MHET II/5, 796)

— : $6 \mathrm{iku} /$ Saškum (MHET II/5, 800)

— : $4 \mathrm{iku} /$ Ebirtum (MHET II/5, 813)

—: $\quad 3 \mathrm{iku}+/$ birìt nārîm (MHET II/5, 827)

Ina-libbi-eršet (nadītum), daughter of Warad-ilišu

Aṣ04: $7 \mathrm{iku} /$ a.gàr 0.1.3 iku.e (MHET II/4, 506)

Aṣ08: $6 \mathrm{iku} /$ še.gi ${ }_{6}($ MHET II/4, 514)

Aṣ17+b: — iku / Bu[ ... ] (MHET II/4, 555)

- : - / - (MHET II/5, 736)

Kuzābatum, daughter of Nūr-Šamaš

Si11: $6 \mathrm{iku} /$ Haganum (MHET II/3, 419)

— : $6 \mathrm{iku} /$ Haganum (MHET II/5, 719)

— : $6 \mathrm{iku} /$ Haganum (MHET II/5, 780)

Lamassi (nadītum), daughter of Iddin-Sîn

H01: $\quad x+2 \mathrm{iku} /$ a.gàr gu.la (MHET II/2, 139 $9^{29}$ )

H35: mala mașu / a.gàr gu.la (MHET II/2, 262)

Si01: $3 \mathrm{iku} /$ a.gàr gu.la (MHET II/3, 351)

Si02: $30 \mathrm{sar} /$ - (MHET II/3, 362)

Si02: mala mașû / — (MHET II/3, 363)

Si03: $\quad 1 / 2$ šu.ši / — (MHET II/3, 371)

Si03 or 04: $1 \mathrm{iku} /$ - (MHET II/3, 373)

Si09: $3 \mathrm{iku} /$ a.gàr GAL? (MHET II/3, 375)

Mannatum (nadītum), daughter of Yassi-El

H14: $18 \mathrm{iku} \mathrm{/} \mathrm{a.gàr} \mathrm{Martu} \mathrm{(MHET} \mathrm{II/2,} \mathrm{175)}$

H22: $\quad$ mala mașû / — (MHET II/2, 208)

$\mathrm{H}-\mathrm{i}: \quad 8 \mathrm{iku} /$ - (MHET II/5, 583)

H_: _ - / a.gàr Martu (MHET II/5, 715)

Masmaratum (nadītum), daughter of Ahušina

H07: $\quad$ mala mașû / Mahana (MHET II/2, 148)

H14: $6 \mathrm{iku} /$ Mahana (MHET II/2, 174)

H15: mala mașû / Mahana (MHET II/2, 177)

H15: $6 \mathrm{iku} /$ Mahana (MHET II/2, 185)

Si15: $7 \mathrm{iku} /$ - (MHET II/3, 429)

- : $6 \mathrm{iku} /$ Mahana (MHET II/5, 712)

- : $6 \mathrm{iku} /$ Mahana (MHET II/5, 741)

— : _ Mahana (MHET II/5, 771)

${ }^{29}$ MHET II/2, 139 is included here in spite of the lack of her patronym, because the field is in the irrigation district of Gula as in the other two texts. 
—: $3 \mathrm{iku} /$ Piti[...] (MHET II/5, 804)

— : $7 \mathrm{iku} /$ Saškum (MHET II/5, 807)

— : $6 \mathrm{iku} /$ - (MHET II/5, 811)

Narāmtum, daughter of Šamaš-tillassu

H26: mala mașî / — (MHET II/2, 219)

H33: 3 iku / Šalim-bēlī (MHET II/2, 254)

Sm03 or H27: mala maṣ̂u / Huba (MHET II/5, 687)

Ruttum (nadìtum), daughter of Hammurabi ${ }^{30}$

H21: $12 \mathrm{iku} /$ a.gàr [ ${ }^{\mathrm{d} G I R]}$ (MHET II/2, 204)

H24: $14 \mathrm{iku} /$ Gizanum (MHET II/2, 209)

H24: $\quad$ a.šà u maškanum mala mașû / gú ud.kib.nun ${ }^{\text {ki }}$ (MHET II/2, 212 [case])

Si25: $18 \mathrm{iku} /$ Appaya (MHET II/3, 441 [case])

Ruttum (nadìtum), daughter of Iși-Qatar ${ }^{31}$

H38: $19 \mathrm{iku} /$ Pahușum (MHET II/2, 273)

H38: $6 \mathrm{iku} /$ ša-Amkanum (MHET II/2, 274)

H42: $12 \mathrm{iku} /$ Lugal.sag.íla (MHET II/2, 302)

H42: $18 \mathrm{iku} /$ Pahusumum (MHET II/2, 306)

H43: $9 \mathrm{iku} /$ erasure (MHET II/2, 312)

$\mathrm{H}-$ : $18 \mathrm{iku} /$ Appaya (MHET II/5, 612)

H-: — iku / Bura (MHET II/5, 772)

Si02: $19 \mathrm{iku} /$ Pahușum (MHET II/3, 368)

Si06: $15 \mathrm{iku} /$ Gizanum (MHET II/3, 397)

Si26: 18 iku / Pa[hușum] (MHET II/3, 443)

Si-: $15 \mathrm{iku} /$ Gizanum (MHET II/5, 744)

Šāt-Aya (nadītum), daughter of Ikūn-pî

Alone:

H40: $7 \mathrm{iku} /$ Buša (MHET II/2, 278)

H40: $3 \mathrm{iku} /$ - (MHET II/2, 279)

H40: $3 \mathrm{iku} /$ Buša (MHET II/2, 289)

H-: $3 \mathrm{iku}$ ? / Buša (MHET II/5, 644)

Together with Geme-Aya, ${ }^{32}$ daughter of Nūr-ilišu: ${ }^{33}$

H40: $7 \mathrm{iku} / \mathrm{Buša}(\mathrm{MHET}$ II/2, 280)

${ }^{30}$ Hammurabi here is only a namesake of King Hammurabi. A princess is usually designated as "daughter of the king (dumu.mí lugal)."

${ }^{31}$ Dekiere reads the woman's name Izi-gatar (MHET II/2, 266) instead of İși-Qatar.

${ }^{32}$ The name of this woman is often written géme- ${ }^{\mathrm{d}} a$ - $a$ (MHET II/2, 227, 265, 271, 280, 291), but such spellings as géme $^{\mathrm{me}}$-ia (MHET II/2, 259, 310), ge-me- ${ }^{\mathrm{d}} a-a$ (MHET II/2, 213, 269) and ge-me-ia (MHET II/2, 293) also appear. It is likely that these are variants of the name of the same woman. Judging from the spelling, ge-me- ${ }^{\mathrm{d}} a-a$ (MHET II/2, $213,269)$ it is likely that her name was pronounced Geme-Aya and not Amat-Aya.

${ }^{33}$ See MHET II/2, 265. However, her father's name may have been $n u$-úr-i-li $i$ as in MHET II/2, 280.

34 Šăt-Aya appears with Geme-Aya as landlady in MHET II/2, 213, 259, 265, 269, 271, 291, 293 and 310, but it is not certain whether these two women are the same as those in MHET II/2, 280, because Šăt-Aya and Geme-Aya (written: géme- $\left.{ }^{\mathrm{d}} a-a\right)$, both daughters of Puzur-Ninurta, appear as landladies in a field lease contract dated to Hammurabi's $27^{\text {th }}$ year (MHET II/2, 227). Their field was also located in the irrigation district of Buša. 


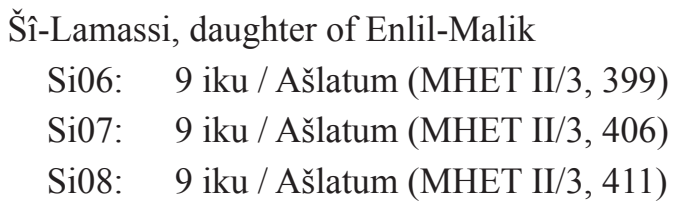

Of these twenty-two prominent (nadìtum-)women only five appear in Harris' (1962, 1-12) list of naditum-women who appear more than three times in the texts from Sippar available at the time of her writing, namely Amat-Šamaš, daughter of Sîn-iddinam, Huuššutum, daughter of Sînpuțram, Ina-libbi-eršet, daughter of Warad-ilišu, Mannatum, daughter of Yassi-El and Narāmtum, daughter of Šamaš-tillassu.

Most, but not all of the names of these (naditum-)women listed above were culled, though not exclusively, from British Museum's collection $\mathrm{Bu}$ 91-5-9, an overwhelming part of which is said to have come from Tell ed-Der (ancient Sippar-Amnānum) (Kalla 1999, 222). They are:

Amat-kallātum (nadītum), daughter of Šamaš-ilum,

Amat-Šamaš (nadītum), daughter of Mašum,

Amat-Šamaš (nadītum), daughter of Sîn-iddinam,

Amat-Šamaš, daughter of Warad-Šamaš,

Bēlessunu (nadītum), daughter of Kazatum (MHET II/ 2, 309 is from Bu 94-1-5),

Eli-erēssa (nadītum), daughter of Akiyatum,

Eli-erēssa (nadītum), daughter of Sîn-abušu,

Erišti-Aya, daughter of Nabī-ilišu,

Erišti-Aya, daughter of Bununum,

Huššutum (nadītum), daughter of Sîn-puțram (MHET II/ 2, 160 and MHET II/5, 610 are from $\mathrm{Bu}$ 94-1-5),

Huzālatum (nadītum), daughter of Sumurah,

Ina-libbi-eršet (nadītum), daughter of Warad-ilišu,

Kuzābatum, daughter of Nūr-ilišu (MHET II/5, 780 is from Bu 81-5-9),

Lamassi, daughter of Iddin-Sîn,

Mannatum (nadītum), daughter of Yassi-El,

Masmaratum (nadītum), daughter of Ahušina,

Ruttum (nadītum), daughter of İși-Qatar (MHET II/2, 302; II/3, 368; and II/5, 612 are from $\mathrm{Bu}$ 94-1-15),

Šî-Lamassi, daughter of Enlil-Malik.

Only the name of Šăt-Aya (nadītum), daughter of Ikūn-pî is culled from the texts in AH 82-9-18 which are said to have come from Abu Habba (ancient Sippar Yahrurum) (Kalla 1999, 219).

The rest of the names are taken from $\mathrm{Bu}$ 89-10-14 (Aya-tallik [nadītum], daughter of Ahulap-Šamaš and Narāmtum, daughter of Šamaš-tillassu) and Bu 92-5-16, 92-7-9, and 94-1-15 (Ruttum [nadītum], daughter of Hammurabi) that contain tablets from Abu Habba as well as Tell ed-Dēr (ancient Sippar-Amnānum).

Why did many of the records of field lease contracts of nadìtum-women apparently come 
from Tell ed-Dēr and not from Abu Habba where the cloister is supposed to have been located? G. Kalla suggests that these records of field lease contracts were kept not in respective nadìtumwomen's houses in the cloister but in the houses of their fathers, brothers or uncles (Kalla 1999, 213). This is yet to be proved, but the suggestion is worth considering. ${ }^{35}$

A curious thing with MHET II/2, 278 and 280 in which Šăt-Aya, daughter of Ikūn-pî, appears as a landlady is the difference in the rates of rent for the fields of the same acreage (7 $\mathrm{iku}$ ) in the same irrigation district. In MHET II/2, 278 it is stated that the rent is 2 gur (about 600 liters) of barley (a rate of 21.4\%), while MHET II/2, 280 states that the rent is 8 gur (about 2,400 liters) of barley (a rate of $85.7 \%$ ), four times more than that of MHET II/2, 278, although the tenant, the date of the contract, and the terms of lease (eqlam ana errēšutim ina piti atappim ušessi, "he rented out a field for cultivation at the time of opening of an irrigation ditch," in II/2, 278:6-8; 280:6-7) are the same. At the moment, I have no explanation for this difference.

\section{The Size of Field Holding of an Individual Nadītum-Woman}

By adding up the fields leased out by each of the twenty-two prominent (naditum-)women during their residency in the cloister we can gain some idea about the "total" acreage of the fields some of the (naditum-)women accumulated during their residency in the cloister. I count a field of the same size owned by the same naditum-woman in the same irrigation district or location only once, except in the case of MHET II/2, 150 and 151 (see n. 42 below), as a precautionary measure to avoid counting the same field more than once. I also assume that a naditum-woman kept a field for life once she acquired it, because a nadìtum-woman appears only occasionally as seller of a field in MHET II/1-6. ${ }^{36}$

The "total" acreage of the fields accumulated by a naditum-woman during her residency in the cloister varies. ${ }^{37}$ Here we list only the twelve naditum-women who accumulated more than $12 \mathrm{iku}$ according to the ascending order of the "total" acreage.

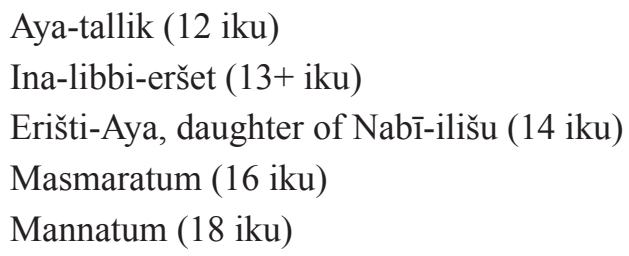

\footnotetext{
${ }^{35}$ This question is also related with the discussion about the last phase of the cloister. C. Janssen $(1991,12)$ thinks that the cloister as the habitation of the naditum-women may no longer have existed after the reign of Samsu-iluna. However, S. Richardson (2002, 181-183; 2010, 332-333), based on the newly published or identified documents that were not available to Janssen, thinks that it remained operative as an institution into the reign of Samsu-ditana, the last king of the first Dynasty of Babylon.

${ }^{36}$ There are thirteen field sale documents in all of which the seller is stated to be a naditum-woman or is quite likely to have been so (MHET II/1, 52, 107; II/2, 134, 161, 238; II/3, 417, 425, 427, 452, 463; II/5, 606, 672, 829). In all of the thirteen texts except in MHET II/1, 52 and II/3, 463, the purchaser also happened to be a naditum-woman.

${ }^{37} \mathrm{R}$. Harris $(1964,122)$ found seven nadìtum-women who resided more than 40 years in the cloister, while J. Renger (1966, 166-168) counted ten nadìtum-women who resided in the cloister more than 40 years. Among our twenty-two prominent nadìtum-women there are three who resided in the cloister for many years, namely Huššutum, daughter of Sîn-puțram (at least 35 years), Huzālatum, daughter of Sumurah (at least 43 years) and Masmaratum, daughter of Ahušina (at least 43 years). Of these only Huššutum appears in the lists of Harris and Renger.
} 
Amat-Šamaš, daughter of Sîn-iddinam $(18 \mathrm{iku})^{38}$

Amat-kallātum (18+ iku)

Šàt-Aya (20 iku)

Huzālatum (24 iku)

Huššutum (34 iku),

Ruttum, daughter of Hammurabi (44 iku),

Ruttum, daughter of İși-Qatar (70 iku)

It is noted that Huššutum, Ruttum, the daughter of Hammurabi and Ruttum, the daughter of İsi-Qatar, accumulated a vast amount of fields to lease out. They may be regarded as "women entrepreneurs" in the field management business in the Old Babylonian Sippar. However, the smaller holdings of the other naditum-women do not necessarily reflect the real situation because our documentation is far from complete.

\section{Conclusions}

1. The two most common acreages of the fields leased out by a (naditum-)woman are 3 iku and 6 iku, although $18 \mathrm{iku}$ (five contracts) and $19 \mathrm{iku}$ 's (two contracts) are also found.

2. If a (nadìtum-)woman has no income other than rent which is paid in kind at a less favorable rate of one third of the yield and if 720 liters of barley is needed for a person to subsist for a year, as posited, for example, by M. Stol, she must have at least $5.4 \mathrm{iku}$ of field under cultivation in any given year on the basis of the yield rate of 400 liters per iku. This would mean that in the alternate fallow system she must have, at least, a total of $10.8 \mathrm{iku}$ of fields in two or more irrigation districts (see No. 7 below).

3. The rent is fixed to one third of the yield in 35 (26.7\%) of the 131 field lease contracts with a (naditum-)woman as lessor dated to the reigns of Hammurabi and Samsu-iluna, but in ten (7.6\%) of the contracts the rent is set to $50 \%$, while in twenty-two contracts $(16.8 \%)$ the rent is set even higher to $75 \%$ of the yield.

4. Normally a lease contract of a field is for one year. Of the forty field lease contracts in MHET II/2-3 dated to the reigns of Hammurabi and Samsu-iluna that contain not only a year name but also a month name, $62.5 \%$ (twenty-five field lease contracts) of them are concluded during the period from Month I (March/April) to Month III (May/June), and the remaining contracts are concluded rather late for the agricultural season in Months IV to VI or early presumably for the coming agricultural season in Months VIII to XII.

5. Many of the tenants seem to be rather affluent individuals, as noted by R. Harris.

6. There are twenty-two (nadītum-)women who appear as lessor in three or more field lease contracts published in MHET II/1-6. The names of these women are mostly, though not exclusively, culled from the British Museum's collection Bu 91-5-9, an overwhelming part of which is said to have come from Tell ed-Dēr (ancient Sippar-Amnānum) and not from AbuHabba (ancient Sippar-Yahrurum) where the cloister is supposed to have been located.

7. There are four naditum-women who accumulated fields of more than $25 \mathrm{iku}$ for leasing,

${ }^{38}$ Amat-Šamaš leased out two fields of 9 iku each in the same location to two different tenants (Mut-Arah and Warassa) in Hammurabi's $9^{\text {th }}$ year. Thus, she must have had two separate fields of the same acreage in the same location. 
namely Huzālatum (25 iku), Huššutum (34 iku), and Ruttum, the daughter of Hammurabi (44 iku) and Ruttum, the daughter of İși-Qatar (70 iku) during their residency in the cloister.

\section{Excursus: Irrigation Districts (a.gàr/ugārum) and the Alternate Fallow System}

So far in my discussion I have assumed that the cereal cultivation in Sippar area used the alternate fallow system. ${ }^{39}$ The fact that the fields of a number of (naditum-)woman were located in two or more irrigation districts (a.gàr/ugārum) can be better understood with the alternate fallow system in mind.

I also noted above that in a text from Sippar-Amnānum dated to Ammi-ditana's $34^{\text {th }}$ year (MHET II/6, 894), nine out of ten $b \bar{a}$ 'irum-soldiers were allotted a total of $12 \mathrm{iku}$ of fields each as subsistence allotments (șibtu-fields) located in two or four different irrigation districts. It would be easier to allot a total of $12 \mathrm{iku}$ of sibtum-fields to each bä'irum-soldier in one batch in one or another irrigation district, but the fact is that the $12 \mathrm{iku}$ of sibtum-fields allotted to each soldier were located in two or four different irrigation districts. The practice of alternate fallow must have been one of the reasons that necessitated such a way of allotting sibtum-fields, ${ }^{40}$ because the alternate fallow system was practiced with the irrigation district as a unit. If one's sibtum-field or fields are found only in one irrigation district, one would have to be idle and thus without harvest in the year following the harvest.

$\S 58$ of the Code of Hammurabi is relevant in this context.

If, after the small cattle (șēnum) come up from the irrigation district (ugārum) when the pennants announcing the termination of pasturing have been wound around the main citygate, the shepherd releases small cattle into a field (eqlum) and allows the small cattle to graze in the field - the shepherd shall guard the field in which he allowed them to graze and at the harvest he shall measure and deliver to the owner of the field 60 gur (= about 18,000 liters) of barley per one bùr (18 iku = about $6.48 \mathrm{ha}){ }^{41}$

$\S 58$ and the preceding $\S 57$ of the Code of Hammurabi have to be read in connection with the practice of allowing small cattle (sheep and goats) to graze young shoots of barley of 4560 days old in the field (Poyck 1962, 52; Charles 1990, 61). In the case of $\S 58$ of the Code of Hammurabi, the shepherd let his herd to graze "illegally" in a field of one particular field-owner. However, $\S 58$ seems to indicate that the practice to allow a herd to graze in a barley field or fields is done by the irrigation district as a unit. In other words, fields in this irrigation district are all sown with none in fallow. In my view, $\S 53$ and 54 also seem to suggest that farmers who had their fields in the same irrigation district, which is to say members of the irrigation district ( $m \bar{a} r \bar{u}$ ugārim), cultivated their respective fields in the same cycle of cultivation and fallow.

However, some of our field lease contracts pose questions for our view. For example, three

\footnotetext{
${ }^{39}$ Yamamoto 1979a, 165-214; 1979b, 85-97; 1980, 69-87; LaPlaca and Powell 1990, 75-82 for the Pre-Sargonic period and Liverani 1990, 169. As for the alternate fallow system in mid-20 $0^{\text {th }}$ century Iraq, see Buringh 1960, 71, 249; Poyck 1962, 19, 38; Charles 1990, 47-48, 60-61; Postgate 1990, 65-74.

${ }^{40} \mathrm{It}$ is possible that there were good irrigation districts with a high yield and poor districts with a low yield. In such a situation, it may have been necessary to avoid unbalance of allotting all the șibtu-fields of one $b \bar{a}$ 'irum-soldier either in a good irrigation district or in a poor one.

${ }^{41}$ This translation is based on that of Roth $1995,92 \mathrm{f}$.
} 
lease contracts were concluded for two (MHET II/2, 166) or three consecutive years (MHET II/2, 142 and 148). Further, three separate yearly contracts of field leasing were concluded by ŠîLamassi with her tenant Enlil-malik regarding the field of the same acreage of 9 iku located in Ašlatum in Samsu-iluna's sixth to eighth year with an annual rent of $41.7 \%$ to $54.2 \%$. However, in these cases the lessees of these contracts, especially those of MHET II/2, 142, 148 and 166, quite possibly cultivated the fields for two or three years continuously because of the poor conditions of the fields they rented. ${ }^{42}$

There are other field lease contracts that pose a more serious question for our view of the alternate fallow system. Let us examine seven field lease contracts, all located in the irrigation district of Buša, and dated to various regnal years of Hammurabi: MHET II/2, 227 (H 27), 265 (H37), 271 (H38-I), 278 (H40), 280 (H40), 289 (H40-IV), 291 (H40-VI). ${ }^{43}$ Of these seven lease contracts, five are dated to Hammurabi's even regnal years, but two, MHET II/2, 227 and 265, are dated to odd regnal years. If the alternate fallow system was practiced in Sippar, the irrigation district of Buša should have been in cultivation either only in even regnal years or only in odd years. A possible solution is that the two odd-year contracts were written early for the coming year (possibly in Month XI or Month XII). However, since no month name is given in two other field lease contracts (MHET II/2, 278 and 280) that are dated to Hammurabi's even regnal years, the possibility cannot be excluded that they too were written early for the coming year.

Again, there are four lease contracts involving the irrigation district of Mahana, namely MHET II/2, 148 (H7), 174 (H14-V), 177 (H15) and 185 (H15-XII). One of them is dated to Month $\mathrm{V}$ of Hammurabi's $14^{\text {th }}$ year, thus indicating that the irrigation district of Mahana was sown in Hammurabi's even years, but the remaining three field lease contracts are dated to Hammurabi's odd years. These four contracts therefore do not seem to support the idea that the irrigation district constitutes a unit for the alternate fallow system. However, MHET II/2, 185 is dated to H15-XII near the end of the year, meaning that it was written early for the agricultural work of the coming year, namely Hammurabi's $16^{\text {th }}$ year. Similarly, the remaining two lease contracts (MHET II/2, 148 and 177) may theoretically also have been written early for Hammurabi's $8^{\text {th }}$ and $16^{\text {th }}$ regnal years respectively. In that case these four lease contracts do not necessarily refute our idea that an irrigation district constituted the unit for the alternate fallow system.

To sum up, our data regarding irrigation district (a.gàr/ugārum) do not support nor refute the idea that it was the unit for the alternate fallow system. Unfortunately, I have to let this matter rest unsolved at this point.

\section{Bibliography}

Buringh, B. 1960: Soils and Soil Conditions in Iraq, Baghdad.

\footnotetext{
${ }^{42}$ Note the relatively low rates of the rent of the field of MHET II/2, 142 (18.8\% of the yield in the first year and 37.5\% in the second year. No amount of rent is given for the third year). The rental rate of the field of MHET II/2, 166 was only $12.5 \%$ per year. As for MHET II/2, 160, the yearly rent is said to be mere 100 liters. Possible exceptions to the alternate fallow system in the Pre-Sargonic period are suggested by Sh. Yamamoto (1980, 176f.). For cases of continuous cultivation of the fields because of their poor yield in modern Iraq, see Poyck 1962, 38f.

${ }^{43}$ The Arabic numeral in parentheses indicates the year, while Roman numerals indicate the month.
} 
Charles, M. P. 1990: “Traditional Crop Husbandry in Southern Iraq 1900-1960,” BSA 5, 47-64.

Clark, C. and M. Haswell. 1970: Economics of Subsistence Agriculture, London.

Dekiere, Luc. 1994-97: Old Babylonian Real Estate Documents from Sippar in the British Museum, Mesopotamian History and Environment, Series III, Texts, Vol. II, Parts 1-6, Ghent.

De Graef, K. 2002: "An account of the redistribution of land to soldiers in late Old Babylonian Sippar-Amnānum," JESHO 45, 141-178.

Harris, R. 1962: "Biographical Notes on the naditum-women of Sippar,” JCS 16, 1-12.

Harris, R. 1964: "The nadītu-woman," in Studies Presented to A. Leo Oppenheim, Chicago, 106-135.

Harris, R. 1975: Ancient Sippar: A Demographic Study of an Old-Babylonian City (1894-1595 B.C.), Istanbul.

Janssen, C. 1991: "Samsu-iluna and the Hungry nadītums," in Northern Akkad Project Reports 5, Mesopotamian History and Environment, Series I, Ghent, 3-39.

Kalla, G. 1999: "Die Geschichte der Entdeckung der altbabylonischen Sippar Archiv," ZA 89, 201-226.

LaPlaca, P. J. and M. A. Powell. 1990: "The Agricultural Cycle and the Calendar at Pre-Sargonic Girsu," BSA 5, 75-82.

Liverani, M. 1990: "The Shape of Neo-Sumerian Fields,” BSA 5, 147-186.

Maekawa, K. 2011: Zusetu Mesopotamia-shi (Illustrated History of Mesopotamia) (in Japanese), Tokyo.

Mauer, G. 1980: Das Formular der altbabylonischen Bodenpachtverträge, München.

Nakata, I. forthcoming: "Economic Activities of naditum-Women of Šamaš Reflected in the Field Sale Contracts Published in MHET II/1-6," in B. Lion and C. Michel (eds.), The Role of Women in Work and Society in the Ancient Near East, Berlin and Boston.

Oates, J. 1980: "Land Use and Population in Prehistoric Mesopotamia," L'archéologie de l'Iraq du début de l'époque néolithique à 333 avant notre ère, Paris, 303-314.

Postgate, J. N. 1990: “A Middle Tigris Village,” BSA 5, 65-74.

Poyck, A. P. G. 1962: Farm Studies in Iraq, Mededelingen van de landbouwhogeschool te Wageningen, 62 (1), Wageningen.

Renger, J. 1967: “Untersuchungen zum Priestertum in der altbabylonischen Zeit, 1. Teil,” ZA 58, 110-188.

Richardson, S. F. 2002: "The Collapse of a Complex State: A Reappraisal of the End of the First Dynasty of Babylon, 1683-1597 B.C.," Ph.D. dissertation, Columbia University (UMI Number: 3053344).

Richardson, S. F. 2010: "A Light in the gagûm Window: the Sippar Cloister in the Late Old Babylonian Period," in Opening the Tablet Box. Near Eastern Studies in Honor of Benjamin R. Foster, Culture \& History of the Ancient Near East 42, Leiden and Boston, 329-346.

Roth, M.T. 1995: Law Collections from Mesopotamia and Asia Minor, SBL Writings from the Ancient World Series, Atlanta.

Stol, M. 1998: "The Care of the Elderly in Mesopotamia in the Old Babylonian Period," in Stol, M. and S. P. Vleeming (eds.), The Care of the Elderly in the Ancient Near East, Leiden.

Stone, E. C. and D. I. Owen. 1991: Adoption in Old Babylonian Nippur and the Archive of Mannum-mešu-lișsur, Winona Lake.

Woestenburg, E. 1997-98: Review of M. Dekiere, MHET II, AfO 44-45, 349-60.

Yamamoto, Shigeru. 1979a: "On the Establishment of the 'Agricultural Year' through Pre-Sargonic Texts of Lagash," Shirin 62, 165-214 (in Japanese).

Yamamoto, Shigeru, 1979b, “The 'Agricultural Year' in Pre-Sargonic Girsu-Lagash,” ASJ 1, 85-97.

Yamamoto, Shigeru, 1980: “The 'Agricultural Year' in Pre-Sargonic Girsu-Lagash (II),” ASJ 2, 169-187. 